of a population is to be indeed constant, the net reproduction rate must be less than 1.0. But stability may in many eyes be preferably defined as net reproduction rate $=1.0$.-Editor, Nature.

\section{Concern and Hysteria}

SIR,-Since your criticism of the assault by environmentalists (Nature, 235, 63 ; 1972), the controversy has spread. For spectators like myself, who may be likened to keen supporters in the stands, the game being played seems to be so loaded with effects that we cannot be certain which side to support or exactly what the rules of the game are. What is certain is that if the pessimists are going to win, or even if the result is a draw, the worldwide result means drawn curtains in many countries of the globe.

Instead of waiting until the turn of the century to decide about the result, an objective look at the world now, from my luxurious position in a safe seat, causes some doubts in my mind. As I read the Sunday papers I learn about the present situation in Bangladesh. We all know in our secure countries of Europe that nothing will be done to alter the misery of those thousands of poor people. And nearer home we can watch the Irish play their revolution game, knowing that neither side will be any better off when it's all over, like Bangladesh but not quite so horrendous. The Irish have cause to remember their history and the death of thousands during the potato famine, but it has no real bearing on present quarrels except to show that the futile death of thousands in misery is easily accepted by the rest of the world. Lessons are not learnt through sacrifices of the poor, who are easily placed in a position to suffer by the limited imagination and false ideals of their educated leaders.

Could my grandchildren become such victims of a conflict or decline in our society? If they are to be safe, what is the price we are paying, or are we stealing their safety? By stealing I mean the "poor nations" bad deal" and feel worried by the threats made recently at the Santiago conference by Dr Salvador Allende, speaking at the UNCTAD III for the whole of the third world.

Apart from our moral position in relationship to the rest of the world we are in some danger of running out of essential supplies of phosphate for food production in 30 years and water in a much shorter time, according to Professor Borgstrom, accentuated by a lack of agricultural scientists and support teams for food production, according to Professor Borlaug, who says that planning often fails to become action in the field.

Surely to minimize the danger of future disintegration in society happening in a variety of ways throughout the world, is taking up a responsibility for consequences that should make even the most optimistic scientist hesitate, before committing his ideas to publication. Your editorial seems to have had more effective influence and been more widely read than the many separate statements made by various experts in the sciences concerned with these ecological developments. Even my local MP was able to quote it as a form of reassurance to me!-adding that it was up to people like me, the average citizen, to do something about the situation. Quite rightly he stated that politicians can only legislate when public opinion is in favour of such developments and action. So your reassurance of the future is as effective as the calm voice of the captain telling us that everything is under control as the ship is foundering in some strange invisible storm.

Every authority I've read to date concerned with environmental developments believes very positively that the solutions can be found through "education". As this is my special area for action I would like to know who the educators are, and when and where do they operate? The communication of ideas of an abstract nature limits the teaching situation at every stage, and the requirements of any academic or scientific syllabus also prevent abstraction in depth, as your scientific readers must realize. Yet the ecological future of our world and its future problems has this science-fiction content that makes it very difficult to approach, except in a most abstract or imaginative way. For, as you say, there is no positive means by which statistics, meaningful or otherwise, can be related to life, now and in the future. The ease with which pupils and students and teachers can accept, take for granted or become bored with information and ideas is one of the educational problems facing ecological educators. Even the ROSLA Panels considering environmental issues were loath to give any undue preference to ecology as a special subject. In my experience people in society do not want to consider abstract changes. Only when rupture of society is affecting their position do they feel enough motivation to act. Even warnings of positive changes about to happen in the near future do not seem to penetrate the "apathy" or tranquillity" of the individual generally, as is happening in the new rise in local rents and rates. Only when the bill is paid are complaints made, and if voices are silent until we are making payments for the bills threatened by some ecological scientists it seems we will discover too late that we cannot afford the price. We may have spent too freely in the past, we may not have saved up enough to cover the cost, or we may have other changes we did not expect. Whatever reason, the prospect of these debts worries me and I would like to believe that science, technology and government are combining to plan responsibly so that I and my family, and the families of the world, have some future security.

Can this be achieved by educational methods? My own experience gives me feelings of doubt because it seems all the action comes from intellectual minority groups and the dull resignation of the average person or student seems an impenetrable barrier. And if legislation only happens when the majority are in favour of changes, then popular opinion will prevent politicians from making unpopular acts. This seems the great weakness of the first issue of the "Blueprint". Even the British Humanists Association's "People First", containing as it does such weighty evidence against any kind of complacency towards worldwide conditions of deterioration of civilized standards and disintegration of most ecological chains, is hoping for "humanist" ideals to affect the conditions of life. There would be real hope for the world if such campaigns could reach out and achieve their ams, but the BHA is itself struggling to survive in spite of an ever increasing rejection of Christian faith.

What I hope to see is further support of your "Case Against Hysteria", backed by sound scientific facts and developments. There must be many active scientists who feel the assault of the environmentalists is still a "bandwagon" activity.

I look forward to hearing more from you all to counteract the other teams' depressing summaries and hope sincerely that the optimists come out as a winning side.

Your side has its attitude reinforced by a recent article by David Hessayon's shortened version of his 8th Tennant Memorial Lecture which he gave before the Society of Chemical Industry at the University of Strathclyde Iast February. This has just appeared in She (May 1972), a widely circulated magazine, and has been handed to me by one of my young students. I'm afraid that this scores over the poorly attended Albert Hall rally meeting to arouse interest in the actions to safeguard the Earth's vanishing wild life; scores in effects of communicating with a wide range of our society, as against a relative few (who are probably pet lovers feeding their animals pet food from tins of whale meat).

\section{Yours faithfully,}

GORDON YATES

Gordale,

14 Frays Avenue,

West Drayton,

Middlesex 